\title{
DETECTION OF THE ANTIMICROBIAL ACTIVITY OF SILVER NANOPARTICULES BIOSYNTHESIZED BY STREPTOCOCCUS PYOGENES BACTERIA
}

\author{
M. M. Kadhum \\ N. N. Hussein \\ Researcher \\ Assist. Prof .
}

Department of Applied Sciences, Biotechnology, University of Technology, Iraq minamohamed17@yahoo.com nehiahussein@yahoo.com

\section{ABSTRACT}

This study was aimed to biosynthesized silver nanoparticles by Streptococcus pyogenes bacteria and its antimicrobial activity against (S.aureus, $P$. aeruginosa, E.coli, and C. albicans yeast) at different concentrations $(20,40,60,80$ and 100$) \mu \mathrm{g} / \mathrm{ml}$ by agar well diffusion assay. Fifty sample was collected from Wounds and burns, from Baghdad Teaching City Medicine Laboratories. Samples identified by culture, VITEK 2 Compact system ID-YST kit. The sensitivity of bacterial isolates to antibiotics ware tested and the microbes were more sensitive, resistant and moderate range to antibiotics. Several techniques where used to characterize AgNPs: X-ray Diffraction (XRD), UV-Visible Spectroscopy(UV) and Scanning electron microscope (SEM).The results show that biosynthesized silver nanoparticles are more effective than bacterial supernatant on human pathogenic microbes.

Key words: Biological activity; pathogenic microbes; nanoparticles.

*Part of M.Sc thesis of the $1^{\text {st }}$ auther.

كاظم وحسبن

مجلة العلوم الزراعية العراقية -507-500:51:51) م2020

الكثف عن الفعالية الضد ميكرويية لدقائق الفضة النانوية المصنعة حيويا بواسطة بكتريا

Streptococcus pyogenes

$$
\text { فرينة محمد كاظم التقتيات الاحيائية, قسم العلوم التطبيقية, الجامعة التكنولوجية }
$$

المستخلص

Streptococcus تهدف الاراسة إلى التخليق الحيوي لجسيمات الفضة النانوية باستخدام بكتريا المكورات العقدية

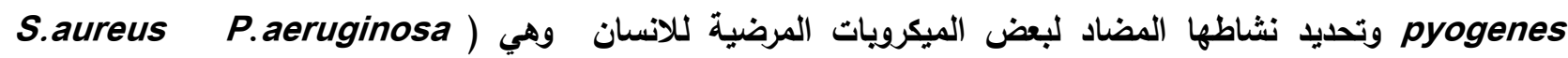
و C. albicans , E.coli ), بتراكيز مختلفة (20, 40, 60, 80 و 100 مكف / مل). تم جمع 50 عزلية من الجروح والحروق من المختبرات التعليمية لمدينة الطب و تم تشخيصها بجهاز الفايتك Vitek. تم اختبار حساسية العزلات البكتيرية للمضادات الحيوية، واظهرت بعض العزلات حساسية عالية وإخى كانت مقاومة لمضادات اخرى ـ تم توصيف دقائق الفضة

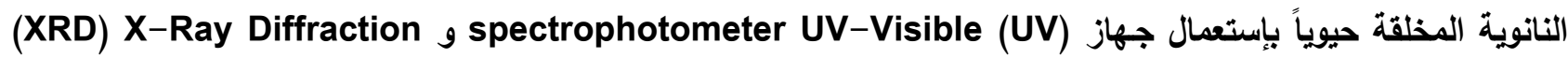
و Scanning electron microscope حيويا على عزلات الاحياء المجهرية واظهرت النتائج أن دقائق الفضة النانوية تمتلك تأثيرا تثبيطيا على نمو الاحياء المجهرية ولثية اعلى من تأثير الراشتح البكتيري. كلمات مفتاحية: الفعالية البايولوجية، الميكرويات المرضية، الدئية الدقائق النانوية "جزء من رسالة ماجستير الباحث الاول. 


\section{INTRODUCTION}

Silver nanoparticles are characterized by unique properties that are not available in other metals and are characterized by antimicrobial properties as well as physical and optical properties that are not available in silver when they are larger in size. The properties of nanoparticles are used in many applications and are important for human life, Medical industry, food industry, food conservation (6).Silver Nanoparticles are a killing agent for a wide range of $\mathrm{G}+\mathrm{ve}$ bacteria, including, Staphylococcus and Streptococcus, and G-ve bacteria, including Acinetobacter, E.coli ,Pseudomonas spp., Salmonella , Vibrio, Bacillus, Clostridium, Enterococcus , and Listeria (20). It is a killing agent of antibiotic resistant strains, which represent methicillin resistant strains and Vancomycin resistant strains. In addition to Antibacterial properties, Silver Nanoparticles have Antifungal, Anti-inflammatory properties (19) To overcome problem utilizing toxic chemicals and high energy required physical procedures, the nanoparticles have been combined by natural materials which have been used for the union of different metal and oxide nanoparticles. Thus, the biogenic methodology, the use of regular living beings or materials specifically, has offered a dependable, basic, nontoxic and ecoaccommodating technique (7). In addition to different types of plants ,many microorganisms, such as algae, fungi and bacteria have been used in nanoparticles synthesis (1). Biosynthesis of metal nanoparticles can occur either intracellularly or extracellularly (9) (10). In this study, Strept. pyogenes bacteria were selected to the biosynthesis of silver nanoparticles.

\section{MATERIALS AND METHODS}

\section{Collection of microbial isolates}

50 microbial isolates belong to Strept. pyogenes, E. coli, C. albicans S.aureus and $P$. aeruginosa were collected from Baghdad teaching city medicine laboratories The isolates were diagnosed by gram stain and biochemical tests. These identified cultures were transferred to nutrient agar slants for preservation and then store in the refrigerator at $4^{\circ} \mathrm{C}(14)$.
Antibiotic susceptibility test: By using disk diffusion assay, by transferred part of colony of microbe grown in BHIB by loop to test tube that contained $5 \mathrm{ml}$ of normal saline and The bacterial suspension was compared to the standard McFarland, then $0.1 \mathrm{ml}$ of the microbe suspension has been spread on the surface of Mueller-Hinton agar, and left to dry. Antibiotic disks were placed on the agar by sterile forceps. After incubation period, The zone of inhibition diameter around the disc is estimated and compared to the CLSI reference table to determine if the organism is susceptible, intermediate or resistant against the antibiotic agents tested (16).

Biosynthesis of silver nanoparticles by Streptococcus pyogenes

The growing $S$. pyogenes strains were freshly injected on Muller_Hinton broth and incubated at $37^{\circ} \mathrm{C}$ for 24 hours. The culture was centrifuged at $14,000 \mathrm{rpm}$ for 10 minutes, supernatant added separately for reaction container containing silver nitratea concentration of $10^{-3}(1 \% \mathrm{v} / \mathrm{v})$. The interaction between this supernatant and $\mathrm{Ag}^{+}$ions was carried out in bright status for 24 hours (8).

Characterization of biosynthesis silver nanoparticles

Characterization of Silver nanoparticle were analyzed by (UV-Vis spectrophotometer and $\mathrm{X}$-Ray diffraction) . Color change of the reaction mixtures was checked by estimating UV-visible range of the reaction mixture .SEM used to determination of the morphology and size of nanoparticles and Xray diffractometer by casting $(\mathrm{CuK} \alpha)$ over the model to be measured at different angles from $20^{\circ}$ to $60^{\circ}$ and measured the results. The Debye-Scherer formula was applied to obtain the size of the synthesized nanoparticles (4). $\mathrm{D}=\mathrm{K} \lambda / \beta$ Cos.

$D$ is the particle size; $K$ is a dimensionless shape factor; $\lambda$ refer to $\mathrm{X}$-ray wavelength; $\beta$ is the line broadening at half the maximum intensity (FWHM); $\theta$ is the Bragg angle (in degrees).

\section{Antimicrobial activity assay}

To determine the antimicrobial activity of the biosynthesized AgNPs by using $S$. pyogenes against other microbial strains that cultured on media and after the plates were permitted to dry, wells ware formed . A $100 \mu \mathrm{L}$ volume of 
biosynthesis AgNPs was applied in the wells , incubated at $37^{\circ} \mathrm{C}$ for $24 \mathrm{hrs}$. the diameter of inhibition zone was estimated around each well , 3 replicate trials were conducted against each microbes (2) .

\section{RESULTS AND DISCUSSION}

Collection of microbial isolates and identification

microbial isolates belong to S. pyogenes, isolated from wounds and burns and diagnosed with VITEK ,API strips, gram stain and subjected to biochemical tests for further confirmation (17).

\section{Antibiotic susceptibility test}

The results in (Table 1) showed that $S$. pyogenes bacteria were the most resistant to antibiotics. The number of antagonists was 6 antibiotics of a total of 10 antibiotics, followed by P.aeruginosa, E. coli and S.aureus. The number of antagonists was 4 antibiotics of a total of 10 antagonists, and C. albicans, were resistant to 3 of the 10 antibiotic agents. The results showed that there is a difference in the sensitivity or resistance of microorganisms to antibiotics, due to the common use of some antibiotics for a long time, led to the evolution of strains resistant to them, and the manufacture of new antibiotics working on sensitive sites in bacteria has made the resistance of bacteria have something so that bacteria are sensitive to these antibiotics (5).

Table 1. Effect of different antibiotics against some human pathogens

\begin{tabular}{|c|c|c|c|c|c|c|c|c|c|c|}
\hline \multirow{3}{*}{ Microbes } & & \multicolumn{9}{|c|}{ Inhibition zone diameter in (mm) } \\
\hline & \multicolumn{10}{|c|}{ Antibiotics symbol } \\
\hline & C & TMP & $\mathbf{A Z M}$ & DO & $\mathbf{A K}$ & PY & CIP & TOB & E & $\mathbf{A M}$ \\
\hline P. aeruginosa & 12 & 6 & 20 & 18 & 32 & 6 & 33 & 15 & 6 & 6 \\
\hline E.coli & 10 & 10 & 6 & 15 & 30 & 6 & 25 & 12 & 6 & 6 \\
\hline S. aureus & 10 & 11 & 6 & 13 & 31 & 6 & 25 & 12 & 6 & 6 \\
\hline C. albicans & 6 & 22 & 18 & 32 & 25 & 6 & 33 & 15 & 12 & 6 \\
\hline S. pyogenes & 20 & 6 & 6 & 30 & 33 & 6 & 6 & 14 & 6 & 6 \\
\hline
\end{tabular}

Note: In the absence of bacterial growth inhibition zones, the disc diameter is $(6 \mathrm{~mm})$.

$\mathrm{C}=$ Chloramphenicol , TMP= Trimethoprim, AZM= Azithromycin, DO=Doxycycline, AK= Amikacin ,PY= Carbenicillin , CIP= Ciprofloxacin, TOB= Tobramycin , E= Erythromycin , AM=Ampicillin

Biosynthesis of AgNPs

The results in (Fig.1) shown of the biosynthesis nanoparticles by using supernatant of $S$. pyogenes with silver nitrate solution on Muller-Hinton broth at a concentration of $1 \mathrm{mM}$ at $\mathrm{pH} 7$ and at room temperature for $24 \mathrm{hrs}$. The change in the mixture color to brown was refer to a positive synthesis (13).

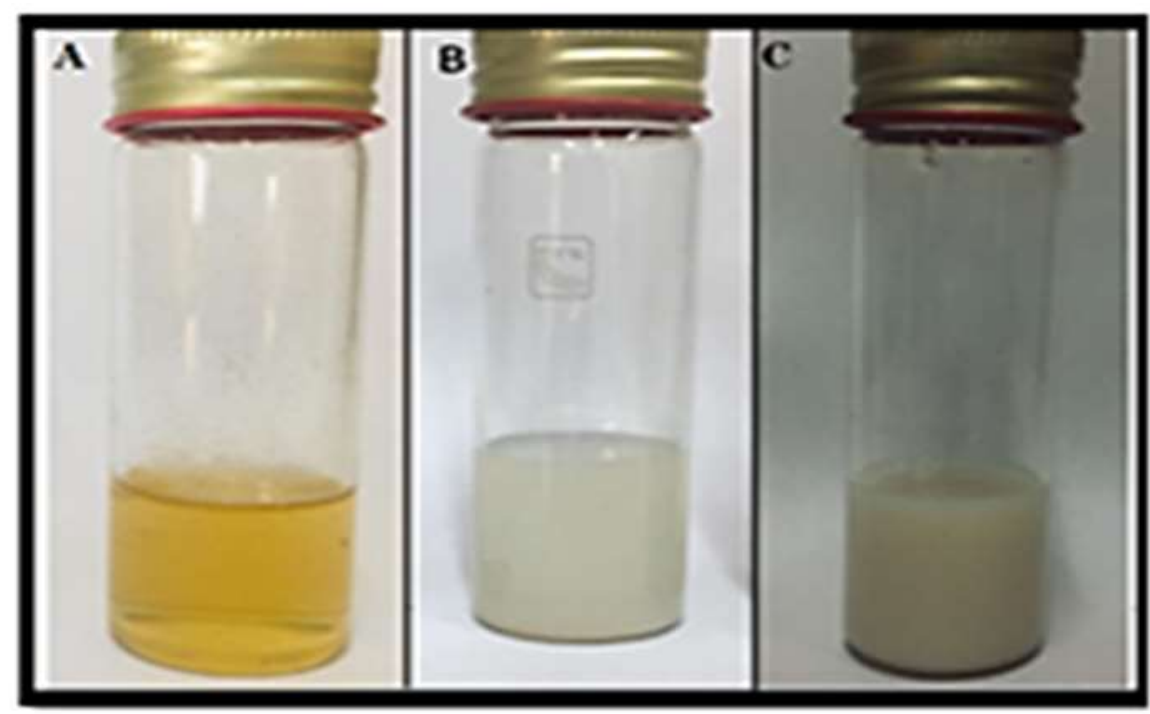

Figure 1. Stages of AgNPs biosynthesis

A= supernatant of $S$. pyogenes $B=$ when adding silver nitrate to the supernatant of S. pyogenes $\mathrm{C}=$ after 24 hours in room temp. synthesis AgNPs

\section{Characterization of AgNPs}

The characterization of nanoparticles show in (Fig.2). By using the UV-Visible spectrophotometer showed the absorption at $\lambda \max$ at $410 \mathrm{~nm}$ wavelength, The phenotypic properties of nanoparticles formed by (SEM), 
Silver nanoparticles appear spherical in shape and Through the X-Ray Diffraction process, the formation of nano-silver at the angle $3 \theta$ was shown in degrees (29.39.32.21 and 31.77). By applying Scherrer equation, the calculated nanoparticles were 30.3 nanometers (13).
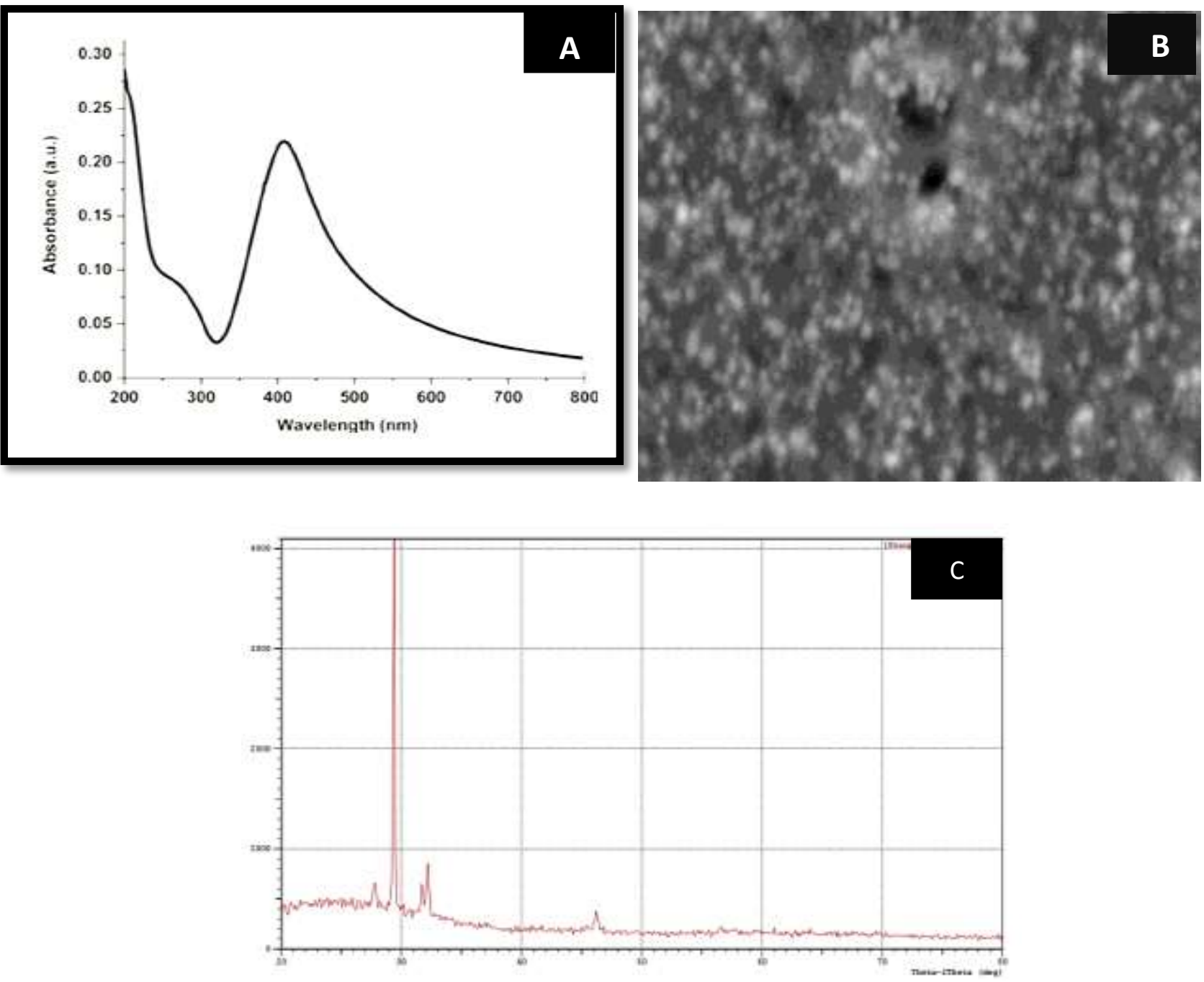

Figure2. Characterization of silver nanoparticles using A= UV-Visible Spectrophotometer $B=$ SEM image of AgNPs C=X-ray diffraction of biosynthesis nanoparticles

Antimicrobial activity of biosynthesis AgNPs

Biosynthensis AgNPs displayed antibacterial properties against bacterial pathogens with close connection of the nanoparticles themselves with the microbial cells. The results showed that the biosynthesized AgNPs by bacteria has a strong inhibitory effect on the growth of pathogenic microbes compared to bacterial supernatant. The supernatant of $S$. pyogenes showed less effective inhibitory effect on P.aeroginosa bacteria in an inhibition zone reached to $13 \mathrm{~mm}$ at concentration of $100 \%$ only (Fig. 3A) . The effect of biosynthesized silver nanoparticles was the highest inhibition on the growth of P.aeroginosa with an inhibition zone reached to of $18 \mathrm{~mm}$ at concentration of $100 \%, 16 \mathrm{~mm}$ at concentration $80 \%, 13 \mathrm{~mm}$ at concentration $60 \%$ (Fig. 3B). 

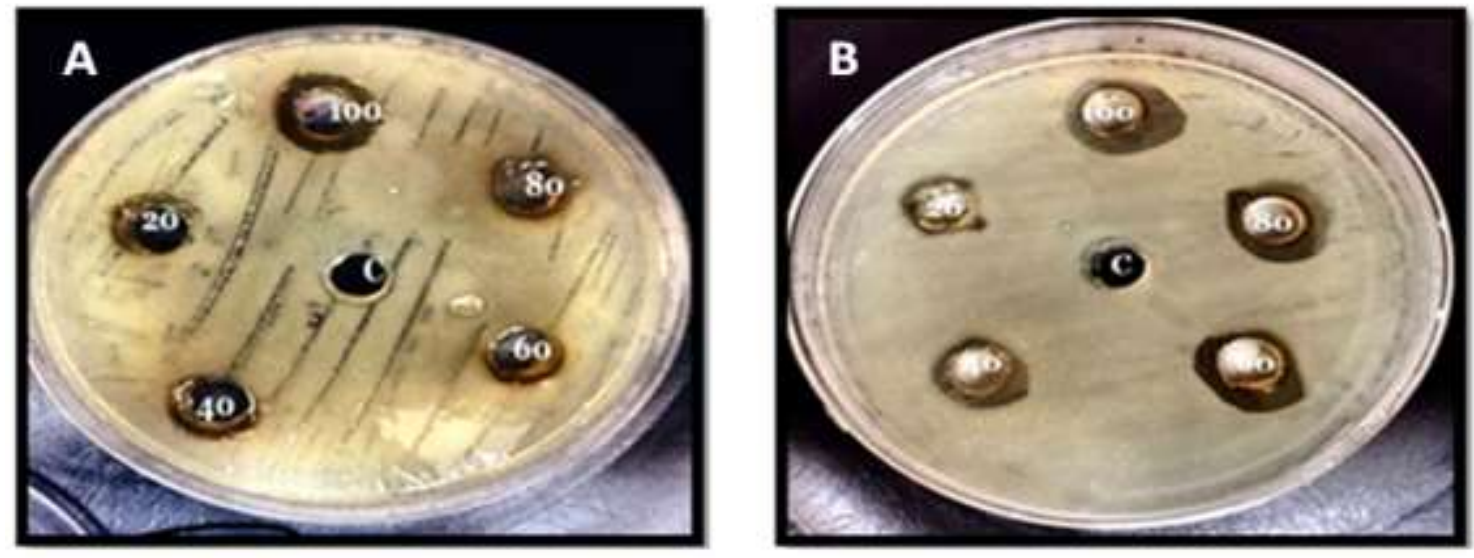

Figure 3.A. The effect of $S$. pyogenes supernatant on P.aeruginosa, B. The effect of biosynthesized sliver nanoparticles on P.aeruginosa

As for S.aureus bacteria where bacterial supernatant showed less inhibitory effect with a $13 \mathrm{~mm}$ at $100 \%$ conc., and $11 \mathrm{~mm}$ at $80 \%$ conc. (Fig.4A), but there's no effect for the other conc. The highest inhibition zone

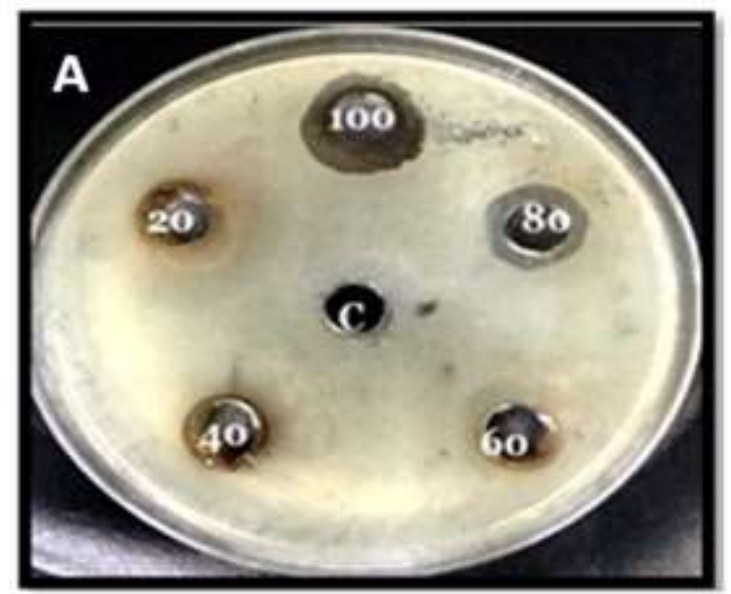

recorded to the biosynthesized silver nanoparticles at $26 \mathrm{~mm}$ for $100 \%$ conc., and $16 \mathrm{~mm}$ at $80 \%$ conc., $14 \mathrm{~mm}$ at $60 \%$ conc., $8 \mathrm{~mm}$ at $40 \%$ conc., and $12 \mathrm{~mm}$ at $20 \%$ conc. (Fig. 4B)

Figure 4. A. The effect of $S$. pyogenes supernatant on S.aureus, B. The effect of biosynthesized sliver nanoparticles on S.aureus.

Followed by E. coli, where bacterial supernatant was less effective inhibition with a $12 \mathrm{~mm}$ inhibitory at $100 \%$ conc. , and $13 \mathrm{~mm}$ at $60 \%$ conc.(Fig. $5 \mathrm{~A})$ The highest effect of the

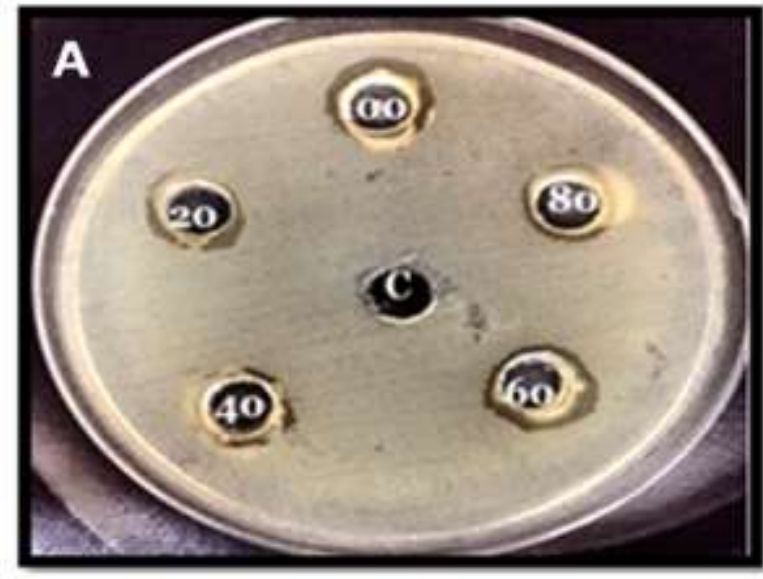

biosynthesized silver nanoparticles reached to $21 \mathrm{~mm}$ at $100 \%$ conc. , $20 \mathrm{~mm}$ at $60 \%$ conc. ( Fig. 5B).

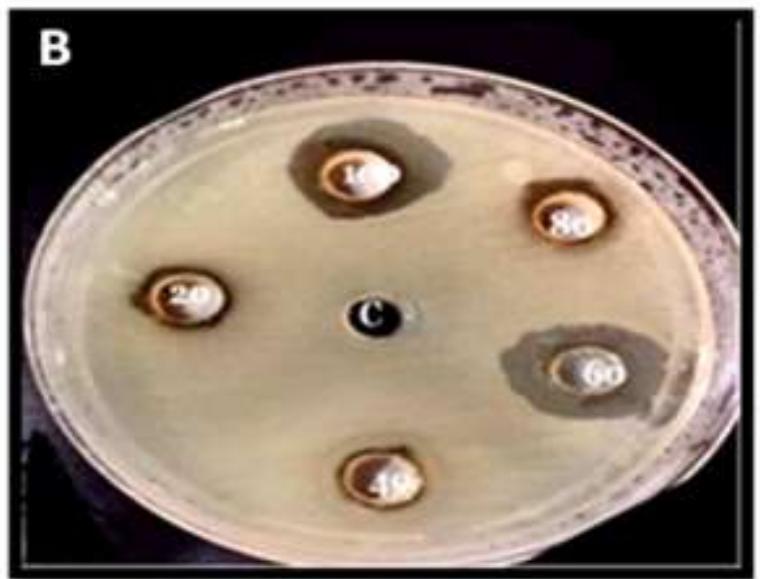

Figure 5.A.The effect of $S$. pyogenes supernatant on $E$. coli , B. The effect of biosynthesized sliver nanoparticles on $E$. coli 
Finally, the yeast $C$. albicans where the effect of bacterial supernatant was less effective inhibition with a $12 \mathrm{~mm}$ inhibitory at $100 \%$ conc. and $12 \mathrm{~mm}$ at $80 \%$ conc.(Fig.6A), The

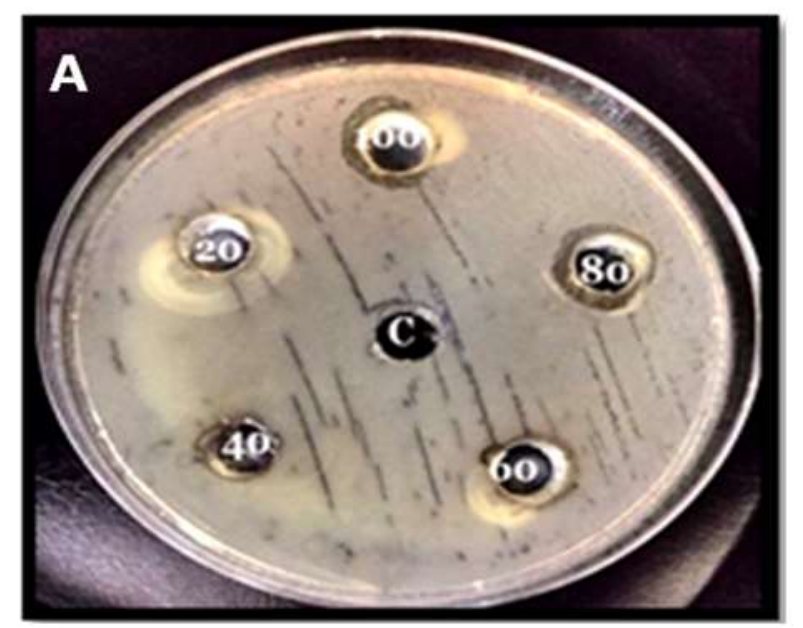

highest effect of the biosynthesized silver nanoparticles at $100 \%$ reached to $23 \mathrm{~mm}, 13$ $\mathrm{mm}$ at $60 \%$ conc., $17 \mathrm{~mm}$ at $60 \%$ conc. and $14 \mathrm{~mm}$ at $40 \%$ conc. (Fig6B).

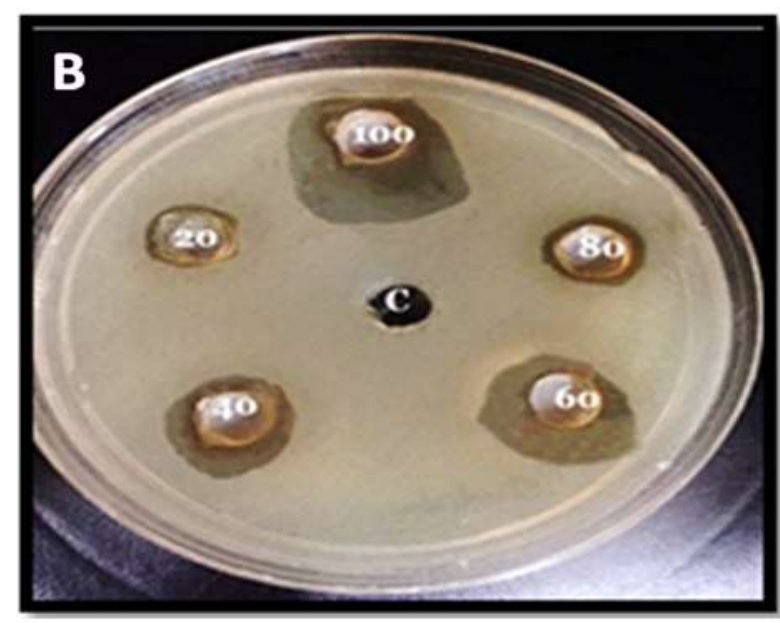

Figure 6 A. The effect of $S$. pyogenes supernatant on C. albicans, B. The effect of biosynthesized sliver nanoparticles on $C$. albicans

Table2. Effect of bacterial supernatant on the growth of microbes

\begin{tabular}{|c|c|c|c|c|c|c|}
\hline Microbes & Control & $20 \%$ & $40 \%$ & $60 \%$ & $80 \%$ & $100 \%$ \\
\hline P. aeruginos & - \pm 0.00 & - \pm 0.00 & - \pm 0.00 & - \pm 0.00 & $11.66 \pm 1.52$ & $14 \pm 1.00$ \\
\hline S.aureus & - \pm 0.00 & - \pm 0.00 & - \pm 0.00 & - \pm 0.00 & $11 \pm 1.00$ & $14 \pm 1.00$ \\
\hline E. coli & - \pm 0.00 & - \pm 0.00 & - \pm 0.00 & - \pm 0.00 & $11 \pm 1.00$ & $12 \pm 1.00$ \\
\hline C. albicans & - \pm 0.00 & - \pm 0.00 & - \pm 0.00 & - \pm 0.00 & $11.66 \pm 0.57$ & $13 \pm 1.00$ \\
\hline
\end{tabular}

Table3. Effect of biosynthesized silver nanoparticles on the growth of microbes

\begin{tabular}{|c|c|c|c|c|c|c|}
\hline Microbes & Control & $\mathbf{2 0 \%}$ & $\mathbf{4 0 \%}$ & $\mathbf{6 0 \%}$ & $\mathbf{8 0 \%}$ & $\mathbf{1 0 0 \%}$ \\
\hline P. aeruginosa & $- \pm \mathbf{0 . 0 0}$ & $- \pm \mathbf{0 . 0 0}$ & $\mathbf{1 6} \pm \mathbf{4 . 1 6}$ & $\mathbf{1 7} \pm \mathbf{3 . 6 0}$ & $\mathbf{1 2} \pm \mathbf{2 . 0 0}$ & $\mathbf{2 0} \pm \mathbf{2 . 0 0}$ \\
S.aureus & $- \pm \mathbf{0 . 0 0}$ & $- \pm \mathbf{0 . 0 0}$ & $\mathbf{1 1 . 3 3} \pm 1.52$ & $\mathbf{1 5} \pm \mathbf{1 . 0 0}$ & $\mathbf{1 7} \pm \mathbf{1 . 0 0}$ & $\mathbf{2 1} \pm \mathbf{1 . 1 5}$ \\
E. coli & $- \pm \mathbf{0 . 0 0}$ & $- \pm \mathbf{0 . 0 0}$ & $- \pm \mathbf{0 . 0 0}$ & $\mathbf{1 7 . 3 3} \pm 3.05$ & $\mathbf{1 1 . 6 6} \pm \mathbf{1 . 5 2}$ & $\mathbf{2 1} \pm \mathbf{1 . 0 0}$ \\
C. albicans & $- \pm \mathbf{0 . 0 0}$ & $\mathbf{1 5} \pm \mathbf{1 . 0 0}$ & $\mathbf{1 5} \pm \mathbf{1 . 0 0}$ & $\mathbf{1 8 . 6 6} \pm \mathbf{1 . 5 2}$ & $\mathbf{1 5 . 6 6} \pm 3.78$ & $\mathbf{2 4} \pm \mathbf{1 . 0 0}$ \\
\hline
\end{tabular}

$*(-)=$ no inhibition occurs

The results show that biosynthesis of Silver nanoparticles are more effective than bacterial supernatant. The supernatant of $S$. pyogenes bacteria have Inhibitory effect on the growth of microbes related to the nature of the substances produced by the bacteria but this effect is weak (3) , But The biosynthesized silver nanoparticles by supernatant of $S$. pyogenes bacteria have a strong inhibitory effect because silver nanoparticles have a very effective against bacterial and fungal infections. These properties are due to silver nanoparticles having a large surface area of the volume ratio which increases their association with bacterial cell well causing changes in the membrane and thus cell death (18) That can also release silver ions that interfere with thiol groups in biomass enzymes, which inhibit them. Silver ions also inhibit respiratory enzymes and during the inhibition process reactive oxygen species are generated. (ROS) that attack the cell itself and thus die. (11) Silver nanoparticles have the ability to interfere with the sulfur and phosphorus bases of DNA and thus lead to the breakdown of DNA and cell death due to a disturbance in the DNA replication of bacteria and microbes (12). This agreement with that the biosynthesis of Silver nanoparticles by S.pyogenes has great effectiveness against broad spectrum of pathogenic microorganisms (15). The present investigation support the use of biosynthesized AgNPs by S.pyogenes elicited a strong antimicrobial activity. Thus, the biological approach could be an economical alternative to conventional chemical and physical assays of AgNP synthesis and would be suitable for the development of a biological process for commercial large-scale creation. AgNPs have wide application in different fields, such as antibacterial. Therefore, the improvement of their synthesis for nanoparticle production is the main objective of nanotechnology (21). 


\section{ACKNOWLEDGEMENT}

This study was supported by the lab of Division of Biotechnology / Department of Applied science / University of Technology / Baghdad / Iraq. We would like to extend our thanks to staff members of the laboratory of Biotechnology division.

\section{REFERENCES}

1.A.Mourato, M.Gadanho, A.R.Lino, and R.Tenreiro , 2011. Biosynthesis of crystalline silver and gold nanoparticles by extremophilic yeasts, Bioinorganic Chemistry and Applications, vol.2011, article ID 546074,pp:2010-2018

2.Ajah,H.A, K.J, Khalaf , A.M, Hasan, and H.A,Aja, 2016. Extracellular biosynthesis of Silver nanoparticles using Sphingomonas paucimoilis, Serratia sp. and Peudomonas aeruginosa and their antimicrobial activities. E.j.b.p.s,3( 6): 1

3.Brown,A.,2007.Benson'sMicrobiological Applications: Laboratory Manual in General Microbiology, Short Version. McGraw-Hill Higher Education, pp:622-627

4.Caroling,G.,S.K.,Tiwari,A.M.,Ranjitham and R., Suja, 2013. Biosynthesis of silver nanoparticles using aqueous broccoli extractcharacterization and study of antimicrobial cytotoxic effects. Asian J. Pharm. Clin. Res. 6, 165-172.144-148

5.Demain, A.L., 2009. Antibiotics: natural products essential to human health. Medicinal research reviews, 29(6): 821-842

6.Gavanji,S., S. S., Sayedipour, M., Doostmhammadi, and B.,Larki, 2014. The effect of different concentration of silver nanoparticles on enzyme activity and liver tissue of adult male wistar rats in - vivo condition .IJSRK, 4(2):182-188

7.Gopinath, V. and P., Velusamy, 2013. Extracellular biosynthesis of silver nanoparticles using Bacillus sp. GP-23 and evaluation of their antifungal activity towards Fusarium oxysporum. Spectrochimica Acta Part A: Molecular and Biomolecular Spectroscopy, 106, :170-174

8.Jeevan, P., K,Ramya, and A.E,Rena, , 2012. Extracellular biosynthesis of silver nanoparticles by culture supernatant of Pseudomonas aeruginosa ,54(6) :1019-1024

9.Kalimuthu, K., R. S., Babu, D., Venkataraman, M.Bilal, and S.Gurunathan, ,
2008. Biosynthesis of silver nanocrystals by Bacillus licheniformis . Colloids and Surfaces B: Biointerfaces, 65(1), :150-153

10.Konop, M., T., Damps, A. Misicka, and L. Rudnicka, , 2016. Certain aspects of silver and silver nanoparticles in wound care: a minireview. Journal of Nanomaterials ,8(6):423

11.Mazzola, P. G., A. F. Jozala, L.C.D.L.Novaes, P.Moriel, and T.C.V. Penna, 2009. Minimal inhibitory concentration (MIC) determination of disinfectant and/or sterilizing agents. Brazilian Journal of Pharmaceutical Sciences, 45(2):241-248

12.Morones, J. R., J. L.,Elechiguerra, A.,Camacho, J. B., K.Holt, J.,Kouri Ramirez, and M.J. Yacaman, 2005. The bactericidal effect of silver nanoparticles. Nanotechnology, 16(10):2346-2353

13.Nehia. N. H. and H. M., Ameen. ,2019. Detection of the antibacterial activity of AgNPs biosynthesized by Peudomonas aeruginosa . Iraqi Journal of Agricultural Sciences-1029:50(2):728-716

14.Omar, M.M. and H.A.,Jabber, 2017. Isolation, screening and identification of bacillus sp. producing a Alkaline protease. The Iraqi Journal of Agricultural Science,48(6) :1493-1503

15.Paul, D. and S. N., Sinha, 2014. Extracellular synthesis of silver nanoparticles using Pseudomonas aeruginosa KUPSB12 and its antibacterial activity. JJBS, 7(4) :245-50

16.Reller L.B., M.,Weinstein, J.H., Jorgensen and M.J, Ferraro, 2009. Antimicrobial susceptibility testing: a review of general principles and contemporary practices. Clinical infectious diseases 49: 1749-1755.

17.Tawfiq, S.M., 2018. Bacteriologigal and genetic study of Pseudomonas aeruginosa isolates. Iraqi Journal of Agricultural Sciences,49(1):27-35

18.Thomas, R., A., Viswan, J.,Mathew, and E.K., Radhakrishnan, 2012. Evaluation of antibacterial activity of silver nanoparticles synthesized by a novel strain of marine Pseudomonas sp, Nano Biomed. Eng, 4(3):139-143.

19.Wayne, P.A., 2007. Clinical and laboratory standards institute. Performance standards for antimicrobial susceptibility testing, 103(1): 273-278 
20.Zarina, A. and A., Nanda, 2014. Combined efficacy of antibiotics and biosynthesized silver nanoparticles from Streptomyces albaduncus .Int J PharmTech Res,(6):18621869.
21.Zhang, Y., D., Yang, Y., Kong, X., Wang, O.,Pandoli and G., Gao, 2010. Synergetic antibacterial effects of silver nanoparticles@ aloe vera prepared via a green method. Nano Biomed Eng, 2(4): 252-257 